\title{
Comparative Bioinformatics Analyses of the Chloroplast Genomes of Vitis vinifera with Two Caucasica Subspecies of Grape Fruit
}

\section{F. Talat ${ }^{1^{*}}$, S. Shahdparvar ${ }^{2}$, and M. Badri Anarjan ${ }^{3}$}

${ }^{1}$ Assistant Professor, Seed and Plant Improvement Research Department, West Azarbaijan Agricultural and Natural Resources Research and Education Center, AREEO, Urmia, Iran

${ }^{2}$ Master Graduate of Horticultural Biotechnology, Saba Institute of Education, Urmia, Iran

${ }^{3}$ Master Graduate of Plant Breeding, Urmia University, Urmia, Iran

\begin{abstract}
Grape (Vitis vinifera) is a genus of tree in the family of Vitaceae. V. vinifera's species belong to Eurasian grapes. The genome of chloroplast is the most comprehensive genome in plants, and it has many features for evolution analyses due to the unique molecular structure and single-parent inheritance. The goals of this research were study and compare of the complete sequences chloroplast genomes of Saperavi and Meskhuri mtsvane from Caucasia subspecies with common grape (Vitis vinifera), as well as genomes structure analysis, gene content, organization and repetitive sequences, codon usage and comparison among genomes. The chloroplast genome of Vitis vinifera is a circular DNA molecule with 160928 base pairs (bp), which is longer than the chloroplast genomes of Saperavi and Meskhuri mtsvane varieties. The large and small unique regions are separated by two inverted repeat regions a, b. In three genomes, the complete genome contains 131 genes, which include 79 protein coding genes, 4 rRNA genes and 30 tRNA genes. In other words, there are totally 113 single-copy genes and 18 double-copy genes located in inverted repeat region (IR) in the three studied genomes. The SSRs of the chloroplast genomes were identified and the results indicated that the chloroplast genomes of Vitis vinifera and Saperavi both have 74 SSRs and Meskhuri mtsvane has 73 SSRs. The chloroplast SSRs are important and useful for genetic diversity studies. Low GC content is a significant feature of plastidic genomes, which is possibly formed after endosymbiosis by DNA replication and repair.
\end{abstract}

Keywords: Vitis vinifera; Saperavi; Meskhuri mtsvane; Chloroplast genome; Complete sequence

\section{Introduction}

The most plastidic genomes contain a pair of inverted repeat regions (IRa, IRb) with 25000 bp each, which are separated by small and large single copy regions of $20000 \mathrm{bp}$ and $80000 \mathrm{bp}$, respectively. Some plant like of Vicia faba [1] and Cryptomeria japonica break this structural conservation by losing of an IR $[2,3]$. Lack of complete chloroplast genome sequences are still one of the major limitations, and the complete chloroplast genome sequences is useful to expanding chloroplast genetic engineering technology of crops [3]. The using of DNA sequences from all of the shared chloroplast genes provide many characters for phylogeny reconstruction compared to previous studies that they have relied on only one or a few genes to address the same questions [4]. However, the all genomes can limit estimation misleading of relationships because of taxon sampling [5-7] and the using of incorrect models of sequence evolution in concatenated datasets $[8,9]$. Thus, there is a growing interest in expanding the taxon sampling of complete chloroplast genome sequences and developing new evolutionary models for phylogenetic analysis of chloroplast sequences [10] to overcome these concerns. The completely sequencing of chloroplast genomes provide a rich source of data that it can be used to address phylogenetic questions [2-6]. Chloroplasts have a low mutation rate with a great deal of conservation in their structure, genome size, gene content and organization. In previous studies it has been reported that, chloroplast genes like $16 S, 23 S, n d h B, p s b A, p s b B, p s b C, p s b D$, pas $A, p s a B$ and $r b c L$ are suitable to study the relationship among higher plants; $y c f 1, y c f 2, a c c D$, matK, rpoC2 and $n d h F$ are more compatible to study the relationship of the close species [11]. The complete sequencing of chloroplast genome of Vitis also provides valuable data for using chloroplast genetic engineering for this economically important plant [12]. Transcriptomics have been famed to be a potent tool to improve the plant genetic architecture and high expression of the foreign protein, low risk of the pollen pollution [13] and no gene silencing [14]. So it is necessary to find out the chloroplast genome in order to design our next generation transcriptomics. All the grapes in the world belong to the Ampelidaceae family, which is also called Sarmentaceae or Vitaceae family, that this family has more than fourteen generas and six hundred species. Among them, the most important genus is vitis, which has two subgenus with different chromosome numbers. Muscadinae subgenus is wild and has fourteen chromosomes $(2 \mathrm{n}=2 \mathrm{x}=40)$. In the sub-genus Ovitis, which is the second subgenus of this family, there are species that they have thirty-eight chromosomes $(2 \mathrm{n}=2 \mathrm{x}=38)$. The only specie that it has been domesticated is Vinifera, which has many varieties and is common in many parts of the world due to the high quality and quantity of crop cultivation. This study was managed to study and comparing the complete sequencing of chloroplast of Vitis vinifera, analyses of its genome structure, gene content, organization, repeat sequence and codon usage. At the same time, the comparison of three sequencing Grape species were performed.

\section{Materials and Methods}

Complete chloroplast genome sequence of Vitis vinifera, Saperavi and Meskhuri mtsvane in FASTA format, with respectively access number (NC_007957.1), (AB856290.1), (AB856291.1) downloaded from NCBI (//http:www.ncbi.nlm.nih.gov/nuccore/term). The studied genomes were annotated with using of DOGMA (Dual Organellar Genome Annotator) [15], after uploading a FASTA-formation file of the complete plastid genome to the program's server. BLASTX and BLASTN searches against a custom database of previously published plastid genomes identified Vitis putative protein-coding genes and

*Corresponding author: Assistant Professor, Seed and Pant Improvement Research Department, West Azarbaijan Agricultural and Natural Resources Research and Education Center, AREEO, Urmia, Iran, Tel: 00989104055682 E-mail: f.talat@areeo.ac.ir

Received November 20, 2018; Accepted December 13, 2018; Published December 21, 2018

Citation: Talat F, Shahdparvar S, Anarjan MB (2018) Comparative Bioinformatics Analyses of the Chloroplast Genomes of Vitis vinifera with Two Caucasica Subspecies of Grape Fruit. J Phylogenetics Evol Biol 6: 208. doi: 10.4172/23299002.1000208

Copyright: @ 2018 Talat F, et al. This is an open-access article distributed under the terms of the Creative Commons Attribution License, which permits unrestricted use, distribution, and reproduction in any medium, provided the original author and source are credited. 
Citation: Talat F, Shahdparvar S, Anarjan MB (2018) Comparative Bioinformatics Analyses of the Chloroplast Genomes of Vitis vinifera with Two Caucasica Subspecies of Grape Fruit. J Phylogenetics Evol Biol 6: 208. doi: 10.4172/2329-9002.1000208

Page 2 of 7

tRNAs or rRNAs. For genes with low sequence identity, the manual annotation were performed, after identifying the position of the start and stop codons, as well as the translated amino acid sequence with using of the plastid genetic code. Gene map and gene distribution of Vitis vinfera, Saperavi and Meskhuri mtsvaneh were performed by OGDRAW V1.1 (Organellar Genome DRAW, http://ogdraw. mpimpgolm.mpg.de/) [16]. REPuter (http://bibiserv.techfak.unibielefeld.de/reputer/) [17] was used in order to locate and count the forward, reverse, complement and palindromic repeats within the intended genomes. For repeat identification, the following constraints were set to REPuter: (i) minimum repeat size of $30 \mathrm{bp}$ and (ii) $90 \%$ or greater sequence identity, based on hamming distance of 3 [3]. Numbers of codons (NCs), the synonymous relative of codon usage (RSCU) and GC composition of codons were calculated for each gene. The analysis was carried out by CODONW 1.4 (http://codonw.sourceforge.net/). Correspondence analysis (COA) has become the method of choice for multivariate statistical analysis of codon usage $[18,19]$. Since there are 59 synonymous codons (61 senses codons less the unique methionine and tryptophan codons).

\section{Results and Discussion}

\section{Overall structure}

The complete chloroplast genome of Vitis vinifera has 160,928 bp length (Figure 1), which is longer than Saperavi (160,927 bp) and Meskhuri mtsvane (160,906 bp). Total genome of Vitis vinifera includes a pair of inverted repeats with $26,358 \mathrm{bp}$ long, separated by a small and large single copy regions with $19,065 \mathrm{bp}$ and $89,147 \mathrm{bp}$, respectively. The length of LSC region in Vitis vinifera is longer than Saperavi and Meskhuri mtsvane. But the length of SSC and IR regions are same in Vitis vinifera and Saperavi, which are different from Meskhuri mtsvane. The coding region of Vitis vinifera's chloroplast genome is $91,872 \mathrm{bp}$ in length, accounting for $57.08 \%$ of the whole plastidic genome, which is same with Saperavi, and similar to Meskhuri mtsvane by $57.14 \%$, genus Alsophila 53.2\% [20], Dendrocalamus latiforus 53.4\% [21], genus Megaleranthis 52.4\% [11]. The chloroplast genome of Vitis vinifera codes for proteins (49.94\%), tRNA genes (1.73\%) and rRNA (5.61\%), similar to coffee [22] and M. esculenta [23]. The non-coding region has a length with $69,661 \mathrm{bp}$ (43.28\% of the genome). The proportions of intragenic spacers and intron are $31.10 \%$ and $12.18 \%$ respectively.

\section{Repeat structure}

Four types of repeats were detected; forward (direct) match, reverse match, complements match and palindromic (inverted) match. Forty nine repeats have a length more than $18 \mathrm{bp}$ that they are shown in Table 1. The complete chloroplast genome of Vitis vinifera includes

\begin{tabular}{|c|c|c|c|}
\hline \multicolumn{4}{|c|}{ Repeat sequence detected in chloroplast genome of Vitis vinifera } \\
\hline Number & Size (bp) & Location & Match Direction \\
\hline 1 & 20 & IGS & $\mathrm{C}$ \\
\hline 2 & 18 & IGS & $\mathrm{F}$ \\
\hline 3 & 18 & IGS & $\mathrm{F}$ \\
\hline 4 & 20 & IGS & $\mathrm{F}$ \\
\hline 5 & 20 & IGS & $\mathrm{F}$ \\
\hline 6 & 20 & IGS,ycf2 & $\mathrm{F}$ \\
\hline 7 & 21 & Trnfm-CAU, trnP-UGG & $\mathrm{F}$ \\
\hline 8 & 21 & Trns-GCU, trns-UGA & $\mathrm{F}$ \\
\hline 9 & 22 & IGS & $\mathrm{F}$ \\
\hline 10 & 22 & IGS & $\mathrm{F}$ \\
\hline 11 & 22 & trnG-GCC & $\mathrm{F}$ \\
\hline 12 & 24 & ACCD & $\mathrm{F}$ \\
\hline 13 & 26 & IGS,INTRON & $\mathrm{F}$ \\
\hline 14 & 30 & ycf2 & $\mathrm{F}$ \\
\hline 15 & 30 & ycf2 & $\mathrm{F}$ \\
\hline 16 & 31 & IGS & $\mathrm{F}$ \\
\hline 17 & 48 & ycf2 & $\mathrm{F}$ \\
\hline 18 & 48 & ycf2 & $\mathrm{F}$ \\
\hline 19 & 18 & Intron, IGS & $\mathrm{P}$ \\
\hline 20 & 18 & IGS & $\mathrm{P}$ \\
\hline 21 & 18 & IGS & $\mathrm{P}$ \\
\hline 22 & 18 & IGS & $\mathrm{P}$ \\
\hline 23 & 19 & IGS & $\mathrm{P}$ \\
\hline 24 & 20 & IGS & $\mathrm{P}$ \\
\hline 25 & 20 & Trns-UGA, trns-GGA & $P$ \\
\hline 26 & 20 & IGS,ycf2 & $\mathrm{P}$ \\
\hline 27 & 20 & IGS & $\mathrm{P}$ \\
\hline 28 & 21 & Trns-UGA, trns-GCA & $P$ \\
\hline 29 & 22 & IGS & $\mathrm{P}$ \\
\hline 30 & 22 & IGS & $\mathrm{P}$ \\
\hline 31 & 22 & IGS & $P$ \\
\hline 32 & 26 & Intron, IGS & $\mathrm{P}$ \\
\hline 33 & 30 & Ycf2 & $\mathrm{P}$ \\
\hline
\end{tabular}


Citation: Talat F, Shahdparvar S, Anarjan MB (2018) Comparative Bioinformatics Analyses of the Chloroplast Genomes of Vitis vinifera with Two Caucasica Subspecies of Grape Fruit. J Phylogenetics Evol Biol 6: 208. doi: 10.4172/2329-9002.1000208

Page 3 of 7

\begin{tabular}{|c|c|c|c|}
\hline 34 & 30 & Ycf2 & $\mathrm{P}$ \\
\hline 35 & 30 & IGS & $\mathrm{P}$ \\
\hline 36 & 30 & IGS, trns-GGA & $\mathrm{P}$ \\
\hline 37 & 31 & IGS,CCSA & $\mathrm{P}$ \\
\hline 38 & 48 & Ycf2 & $\mathrm{P}$ \\
\hline 39 & 48 & $\mathrm{Ycf}$ & $\mathrm{P}$ \\
\hline 40 & 54 & IGS & $\mathrm{R}$ \\
\hline 41 & 18 & IGS, intron & $\mathrm{R}$ \\
\hline 42 & 19 & $\mathrm{IGS}$ & $\mathrm{R}$ \\
\hline 44 & 19 & IGS & $\mathrm{R}$ \\
\hline 45 & 20 & IGS & $\mathrm{R}$ \\
\hline 46 & 20 & atpB & $\mathrm{R}$ \\
\hline 48 & 20 & IGS & $\mathrm{R}$ \\
\hline 49 & 21 & Intron & \\
\hline
\end{tabular}

Table 1: Repeat sequences detected in chloroplast genome of Vitis vinifera. Note: IGS represents intergenic spacer sequence. $F$ represents forward (direct) match, $R$ represents reverse match, $C$ represents complement match, $\mathrm{P}$ represents palindromic (invert) match.

one complementary repeat, seventeen forward repeats, twenty one inverted repeats and nine reverse repeats. The majority of the repeats were located within ycf2 and intergenic spacer regions and few located at ACCD, trnG, trnP, trnS, and intron sequences. The largest repeat in Vitis vinifera and Saperavi is fifty four bp, which is located in IGS. But the largest repeat in Meskhuri mtsvane is seventy five bp, which is located in IGS and rps19, while the most of repeats in all intended genomes of this study are 18-30 bp. Furthermore, 74 simple sequence repeats in Vitis vinifera, Saperavi and also 73 chloroplast SSRs in Meskhuri mtsvane were obtained. The longest repeat is the repeat of "AT", which is $18 \mathrm{bp}$, but the most of the repeats are $\mathrm{A}$ and $\mathrm{T}$ in all three genomes of this study (Table 2).

\section{Gene content}

All genes coded by the chloroplast genome of Vitis vinifera, Saperavi and Meskhuri mtsvane are detected and listed in Table 3. The results showed that the genome analyzed in this study contains 113 unique genes, 18 of which are duplicated in the IR, for a total of 131 genes (Figure 1). There are four ribosomal and 30 distinct tRNA genes, seven tRNA genes and all rRNA genes are duplicated within the IR. The identified genes can be classified according to the gene function, the functional genetic system gene, the photosynthetic system, the biosynthesis and some with unknown function. There are five genes with unknown function in Vitis vinifera's chloroplast genome ( $y c f$ gene) that they were detected and were highly conserved between species [24]. Rps12 is the name of two genes, which has an intron [11], this gene was separated (by an intron) into two parts with including two exons, locating at LSC (5'- end) and IR ( $3^{\prime}$-end). The second important gene of chloroplast genome is $m a t K$, which has $1.5 \mathrm{kbp}$ lengths, and it was detected in the intron of trnK-UUU, and also it is the only gene located in an intron and encodes maturase $\mathrm{k}$ [14]. This gene has both conserved and variable fragments [25] Thus, it is frequently used in phylogenetic studies [26-29].

\section{Codon usage analysis}

The codon usage was analyzed and is in Table 4, ATG and TGG codes for Methionine and Tryptophan have RSCU value=1 [14]. RSCU of the three terminal codons TAA, TGA and TAG checked out for three intended chloroplast genomes. According to RSCU values, Vitis vinifera, Saperavi and Meskhuri mtsvane prefer TAA as their stop codons. The analysis of the composition for the codons showed that

\begin{tabular}{|c|c|c|c|}
\hline Repeat & Repeat Sequence & Number & Max (bp) \\
\hline \multirow{3}{*}{ Mononucleotide } & A & 24 & 16 \\
\cline { 2 - 4 } & C & 1 & 11 \\
\cline { 2 - 4 } & T & 31 & 15 \\
\hline \multirow{3}{*}{ Dinucleotide } & AT & 5 & 16 \\
\cline { 2 - 4 } & TA & 4 & 12 \\
\hline \multirow{3}{*}{ Trinucleotide } & AAT & 1 & 12 \\
\cline { 2 - 4 } & ATA & 4 & 15 \\
\cline { 2 - 4 } & CAG & 1 & 12 \\
\cline { 2 - 4 } & GAA & 1 & 12 \\
\cline { 2 - 4 } & TAT & 1 & 12 \\
\hline
\end{tabular}

Table 2: Simple sequence repeat (SSR) in Vitis vinifera.

$\mathrm{A}+\mathrm{T}$ content at the third position and in all three intended genomes, the $\mathrm{A}+\mathrm{T}$ were $71.3 \%$, which is similar to what was reported for Aalophile [20] and Panax schinseng nees [1]. In NC-plot distribution, ENC (effective number of codons) and GC3s values were calculated (Figure 2). The heterogeneity of codon usage was further confirmed from the GC3s values ranging from $17 \%$ to $58 \%$ with a mean of $41 \%$ and standard deviation of $10 \%$. If the codon usage bias is completely dictated by GC3s the values of NC should fall on the expected curve between GC3s and NC-plot of the Vitis vinifera chloroplast genome shown in Figure 2. The NC values which lie below the expected curve, indicating that these genes have additional codon usage bias apart from compositional bias (Figure 2).

\section{COA analysis}

Since there are 59 synonymous codons (61 sense codons less the unique methionine and tryptophan codons), according to Vitis vinifera, Saperavi and Meskhuri mtsvane chloroplast gene functions, 54 sequences can be classified six categories, the number of the first classified gene is 13, which encoding ribosomal protein. The $r p l$ and $r p s$ genes encode large and small subunit ribosomal protein, the number of the second classified genes is 15 , including of $p s a$ gene, $p s b$ gene, atp gene, pet gene and $r b c L$ gene, also the third category is a conservative gene, $y c f$. The fourth category is translation apparatus genes, including the rpo gene of the RNA polymerase gene family. The fifth type is the miscellaneous proteins gene, for example $a c c D$, the sixth category is unknown function and hypothetical protein gene. Figure 2 shows the diversity among genes in terms of RSCU. In the leftmost of first axis, genes with the greatest codon bias are located, and those with lowest 
Citation: Talat F, Shahdparvar S, Anarjan MB (2018) Comparative Bioinformatics Analyses of the Chloroplast Genomes of Vitis vinifera with Two Caucasica Subspecies of Grape Fruit. J Phylogenetics Evol Biol 6: 208. doi: 10.4172/2329-9002.1000208

Page 4 of 7

\begin{tabular}{|c|c|c|}
\hline & Group & Gene Name \\
\hline \multirow{11}{*}{ 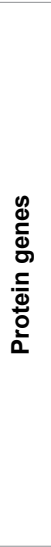 } & Subunit of Acetyl-CoA-carboxylase & $A c c D$ \\
\hline & Small subunit of rubisco & $r b c L$ \\
\hline & Subunit of NADH-dehydrogenase & $n d h A^{*}, n d h B^{*} s, n d h C, n d h D, n d h E, n d h F, n d h G, n d h H, n d h l, n d h J, n d h K$ \\
\hline & Subunits of ATP synthase & $\operatorname{atp} A, \operatorname{atp} B, \operatorname{atp} E, \operatorname{atp} F$, atpH, atpl \\
\hline & Subunits of cytochrome b/f complex & petN, petA, petL, petG, petB, petD* \\
\hline & Subunits of photosystem I AND II & $\begin{array}{c}p s b A, p s b K, p s b l, p s b M, p s b D, p s b C, p s a B, p s a A, p s a l, p s b J, p s b L \\
p s b F, p s b E, p s a J, p s b T, p s b N, p s b H, p s a C, p s b Z, p s b B\end{array}$ \\
\hline & DNA dependent RNA polymerase & $r p o A, r p o B, r p o C 2, r p o C 1^{*}$ \\
\hline & Large subunit of ribosome & $r p / 2^{\star} s, r p / 14, r p / 16^{*}, r p / 20, r p / 22, r p / 23^{s}, r p / 32, r p / 33, r p / 36$ \\
\hline & Small subunit of ribosome & $\begin{array}{c}r p s 2, r p s 3, r p s 4, r p s 7^{\S}, r p s 8, r p s 11, r p s 12^{*} s, r p s 14, r p s 15, r p s 16 *, r p s 18, \\
r p s 19\end{array}$ \\
\hline & Others & $m a t K, \operatorname{cem} A, c / p P^{* *}$, infA, $\operatorname{ccs} A$ \\
\hline & Function unknown & $y c f 3^{* *}, y c f 4, y c f 1^{\S}, y c f 2^{\S}$ \\
\hline 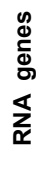 & $\begin{array}{l}\text { Ribosomal RNA genes } \\
\text { Transfer RNA genes }\end{array}$ & 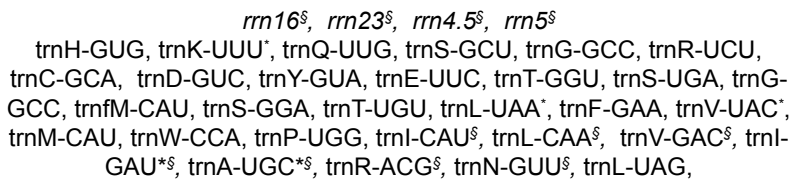 \\
\hline
\end{tabular}

Note: ${ }^{\S}$ reflects gene located in IR; * reflects gene which has one intron; ${ }^{* *}$ reflects gene which has two introns

Table 3: Genes coded by Vitis vinifera chloroplast genome.

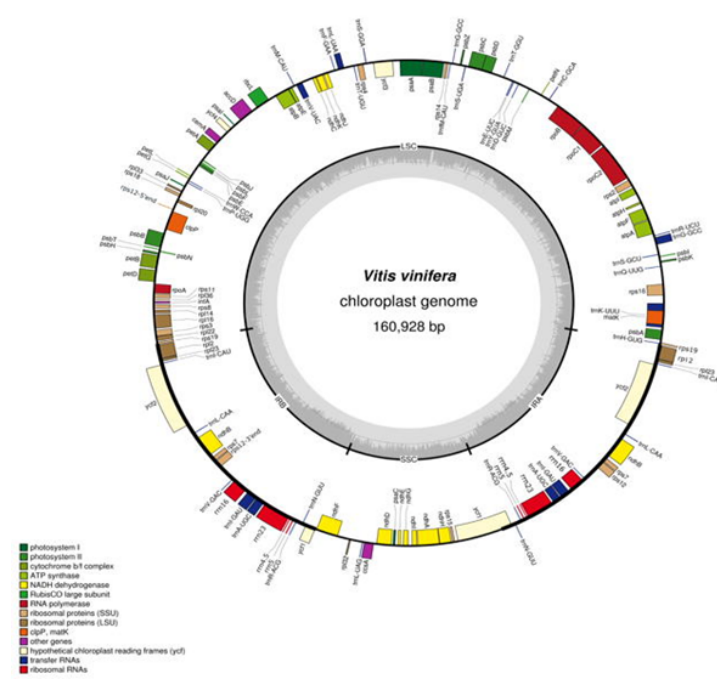

Figure 1: Vitis vinifera's chloroplast genome structure and gene organization. Note: Genes shown outside of the circle transcribed anticlockwise and shown inside of the circle transcribed clockwise. tRNA genes are shown by one letter of the coded amino acid followed by anticodon (genome map was created by using OGDRAW V.1.1. [16].

expansion and contraction based on genome size is considerably important. The extent of IR often affects the large size of the genome and also the pseudo genes of IR, LSC or SSC junctions. In this study, the differences of the junctions between Vitis vinifera, Saperavi, Meskhuri mtsvane and other 3 species (Solanum lycopersicum, Arabidopsis thaliana, Spinacia oleracea) were investigated (Figure 4). The rps19 gene was identified in the IRb/LSC binding region in each of the six genomes compared, indicating that part of the gene was repeated at the IRA and LSC binding site. Comparisons showed that for this gene, Saperavi (38 bp) and Spinacia (144 bp) have the shortest and the longest, respectively. On the border between IRb and SSC, Vitis vinifera, Saperavi and Meskhuri mtsvane were similar, and the $y c f 1$ fragment was 1112,1111 , and $1109 \mathrm{bp}$ on the IRb border, respectively. In Solanum,

\begin{tabular}{|c|c|c|c|c|c|c|c|}
\hline AA & Codon & Number & RSCU & AA & Codon & Number & RSCU \\
\hline \multirow{2}{*}{ Phe } & TTT & 2170 & 1.19 & \multirow{4}{*}{ Ser } & TCT & 1210 & 1.42 \\
\hline & TTC & 1487 & 0.81 & & TCC & 1020 & 1.20 \\
\hline \multirow{6}{*}{ Leu } & TTA & 1115 & 1.24 & & TCA & 931 & 1.10 \\
\hline & TTG & 1143 & 1.27 & & TCG & 618 & 0.73 \\
\hline & СTT & 1102 & 1.22 & \multirow{4}{*}{ Pro } & CCT & 638 & 1.05 \\
\hline & СТС & 716 & 0.80 & & $\mathrm{CCC}$ & 600 & 0.99 \\
\hline & CTA & 797 & 0.89 & & CCA & 772 & 1.27 \\
\hline & CTG & 527 & 0.59 & & CCG & 420 & 0.69 \\
\hline \multirow{3}{*}{ Ile } & ATT & 1845 & 1.22 & \multirow{4}{*}{ Thr } & ACT & 721 & 1.21 \\
\hline & ATC & 1120 & 0.74 & & ACC & 614 & 1.03 \\
\hline & ATA & 1574 & 1.04 & & ACA & 682 & 1.14 \\
\hline Met & ATG & 965 & 1 & & ACG & 372 & 1.62 \\
\hline \multirow{4}{*}{ Val } & GTT & 798 & 1.31 & \multirow{4}{*}{ Ala } & GCT & 459 & 1.25 \\
\hline & GTC & 443 & 0.73 & & GCC & 347 & 0.95 \\
\hline & GTA & 747 & 1.23 & & GCA & 441 & 1.20 \\
\hline & GTG & 446 & 0.73 & & GCG & 217 & 0.59 \\
\hline \multirow{2}{*}{ Tyr } & TAT & 1583 & 1.36 & \multirow{2}{*}{ Cys } & TGT & 701 & 1.19 \\
\hline & TAC & 749 & 0.64 & & TGC & 480 & 0.81 \\
\hline \multirow{2}{*}{ Ter } & TAA & 1180 & 1.21 & Ter & TGA & 945 & 0.97 \\
\hline & TAG & 790 & 0.81 & Trp & TGG & 696 & 1 \\
\hline \multirow{2}{*}{ His } & CAT & 1051 & 1.42 & \multirow{4}{*}{ Arg } & CGT & 384 & 0.70 \\
\hline & CAC & 433 & 0.58 & & CGC & 255 & 0.46 \\
\hline \multirow{2}{*}{ Gln } & CAA & 1124 & 1.41 & & CGA & 574 & 1.04 \\
\hline & CAG & 471 & 0.59 & & CGG & 401 & 0.73 \\
\hline \multirow{2}{*}{ Asn } & AAT & 1892 & 1.42 & \multirow{2}{*}{ Ser } & AGT & 796 & 0.94 \\
\hline & AAC & 772 & 0.58 & & AGC & 525 & 0.62 \\
\hline \multirow{2}{*}{ Lys } & AAA & 2076 & 1.34 & \multirow{2}{*}{ Arg } & AGA & 1085 & 1.97 \\
\hline & AAG & 1028 & 0.66 & & AGG & 600 & 1.09 \\
\hline \multirow{2}{*}{ Asp } & GAT & 1183 & 1.44 & \multirow{3}{*}{ Gly } & GGT & 604 & 1.04 \\
\hline & GAC & 456 & 0.56 & & GGC & 337 & 0.58 \\
\hline \multirow[t]{2}{*}{ Glu } & GAA & 1413 & 1.39 & & GGA & 842 & 1.45 \\
\hline & GAG & 624 & 0.69 & & GGG & 533 & 0.92 \\
\hline
\end{tabular}

Note: Codons shown in bold represents have RSCU value $>1$

Table 4: Codon analysis of Vitis vinifera chloroplast genes that code for proteins. 


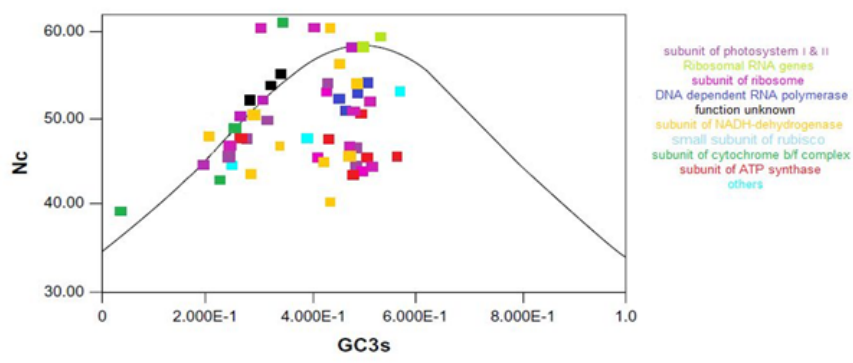

Figure 2: Effective number of codons (NC) used in each gene plotted against GC content at synonymous variable third positions of codons (GC3). The continuous curve plots the relationship between NC and GC3s in the absence of selection.
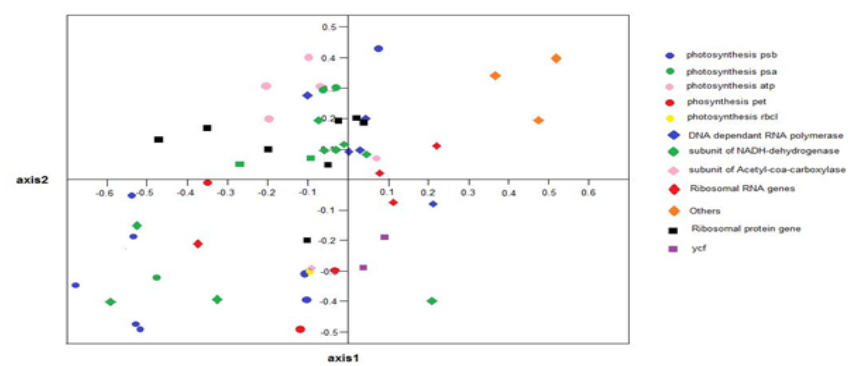

Figure 3: Correspondence analysis of the relative synonymous codon usage in 54 genes from chloroplast genome of Vitis vinifera.

codon bias are found in the rightmost of the axis. Figure 3 shows the plots of ENC values towards GC3 values, given that none of these points have been located on the curve, consequently codon selection of them are not limited to mutation bias of GC3. On the other hand, the codon usage of the points below the curve is dependent from compositional constraint.

\section{Chloroplast SSRs}

Chloroplast SSRs are useful in analysis of genetic diversity, because of their greater efficiency as opposed to genomic SSRs. In addition and due to the greater level of conservation, the information of the other species can be used to design specific primers for a species with unknown sequence data.

\section{Intron}

In all three intended genomes of this study, 18 genes were found containing one or two introns that is the same as in Panax schinseng [1]. The number and location of the intron in chloroplast seems to be conserved. The comparison of introns (Table 5) between Vitis vinifera, Saperavi and Meskhuri mtsvane shows that 18 genes have one or two introns in the chloroplast genome, 6 of which are tRNA coding genes and the rest are protein-coding genes. The longest intron in all three genomes of this study is located in trnK-UUU with $2508 \mathrm{bp}$, which is the only intron in them with another gene, matK inside. The smallest intron with $540 \mathrm{bp}$ is placed in rps12-3 end, which is situated in IR region. Ycf3 and $c l p P$, which are located in LSC are divided by two introns. Intron lengths for $r p s 16$, atpF, $y c f 3-1, r p s 12-3$ end, pet $B$, petD, $r p l 16, n d h B, t r n I-G A U$ and trnA-UGC are conserved, while the others have small variations. Mentioned introns in Table 5 have a high identity, especially $c l p P 1$ and $y c f 3-2$, which has $100 \%$ sequence identity among the studied genomes.

\section{Gene loss in chloroplast genome}

\begin{tabular}{|c|c|c|c|c|c|}
\hline- & Intron & $\begin{array}{c}\text { Vitis } \\
\text { vinifera }\end{array}$ & $\begin{array}{c}\text { Vitis vinifera } \\
\text { subsp. Caucasica } \\
\text { Cultivar: Saperavi }\end{array}$ & $\begin{array}{l}\text { Vitis vinifera } \\
\text { subsp. } \\
\text { caucasica } \\
\text { Cultivar: } \\
\text { Meskhuri } \\
\text { mtsvane }\end{array}$ & $\begin{array}{l}\text { Sequence } \\
\text { Identity } \\
(\%)\end{array}$ \\
\hline 1 & trnK-UUU & 2508 & 2501 & 2501 & 98.57 \\
\hline 2 & rps16 & 900 & 900 & 900 & 99.38 \\
\hline 3 & $\operatorname{trnG-GCC}$ & 710 & 682 & 681 & 97.86 \\
\hline 4 & atpF & 747 & 747 & 747 & 99.50 \\
\hline 5 & rpoC1 & 763 & 759 & 763 & 99.61 \\
\hline \multirow{2}{*}{6} & ycf3-1 & 743 & 743 & 743 & 99.74 \\
\hline & ycf3-2 & 728 & 727 & 727 & 100 \\
\hline 7 & trnL-UAA & 516 & 518 & 518 & 99.49 \\
\hline 8 & trnV-UAC & 573 & 554 & 554 & 99.58 \\
\hline 9 & rps12-3end & 540 & 540 & 540 & 99.88 \\
\hline \multirow{2}{*}{10} & clpP1 & 631 & 633 & 632 & 100 \\
\hline & clpP2 & 810 & 810 & 811 & 99.79 \\
\hline 11 & petB & 688 & 688 & 688 & 99.95 \\
\hline 12 & petD & 734 & 734 & 734 & 99.63 \\
\hline 13 & rpl16 & 1064 & 1064 & 1064 & 99.49 \\
\hline 14 & rpl2 & 664 & 664 & 664 & 99.78 \\
\hline 15 & ndhB & 679 & 679 & 679 & 99.94 \\
\hline 16 & trnl-GAU & 944 & 944 & 944 & 99.89 \\
\hline 17 & $\operatorname{trn} A-U G C$ & 803 & 803 & 803 & 99.70 \\
\hline 18 & ndhA & 1130 & 1129 & 1129 & 99.95 \\
\hline
\end{tabular}

Table 5: The comparison of introns among Vitis vinifera, Saperavi and Meskhuri mtsvane.

The chloroplast genome is a protected genome, but research has shown that a number of genes have been removed or transmitted during the course of evolution. For example $y c f 15$ is also present in all three genomes of this study. InfA, the most mobile gene between chloroplast and nuclear genome, that codes for a translation initial factor 1 is detected in studied genomes of this study. However, some others had the infA as a pseudo gene [24], while in some others infA identified as an intact gene [22]. The results showed that $\operatorname{trnP-GGG}$ was eliminated in all three genomes of this study. According to studies, also this gene is absent in angiosperms, but it has been identified in Cryptomeria japonica [2]. Therefore, it seems that this gene may have been eliminated before the divergence of angiosperms [14]. rpl22, which encodes for large subunit of ribosomal protein 22, was identified in all three chloroplast genomes of this study. In addition, this gene has been deleted in three legumes, Glycine, Lotus and Medicago [3].

\section{Vastness of IR}

The IR range between species is usually different, and the IR 
Citation: Talat F, Shahdparvar S, Anarjan MB (2018) Comparative Bioinformatics Analyses of the Chloroplast Genomes of Vitis vinifera with Two Caucasica Subspecies of Grape Fruit. J Phylogenetics Evol Biol 6: 208. doi: 10.4172/2329-9002.1000208

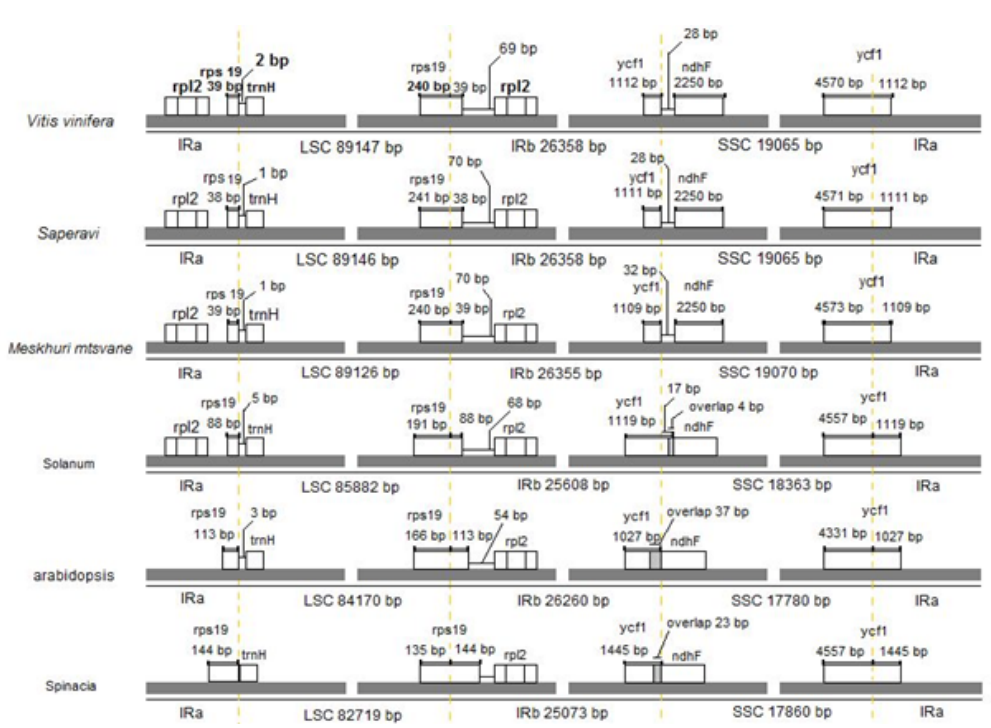

Figure 4: Comparison among LSC, IR and SSC border regions of three common reference species with studied genomes. (Fourth, fifth and sixth rows are derived from [14]).

\begin{tabular}{|c|c|c|c|c|c|c|c|c|c|c|c|}
\hline \multicolumn{12}{|c|}{ GC content of Vitis vinifera chloroplast genome } \\
\hline \multicolumn{6}{|c|}{ Coding Region } & \multicolumn{6}{|c|}{ Non-Coding Region } \\
\hline & Protein & tRNA & & Total & IGS & Intron & Total & $\begin{array}{c}\text { Complete } \\
\text { Genome }\end{array}$ & LSC & ssc & IR \\
\hline Length & 80374 & 2794 & 9036 & 91872 & 50057 & 19604 & 69661 & 160928 & 89147 & 19065 & 26358 \\
\hline Proportion & 49.94 & 1.73 & 5.61 & 57.08 & 31.1 & 12.18 & 43.28 & 100 & 55.39 & 11.84 & 16.37 \\
\hline $\mathrm{T} \%$ & 31.6 & 22.92 & 22.23 & 30.46 & 33.85 & 31.65 & 33.37 & 31.74 & 33.06 & 34.13 & 28.6 \\
\hline$A \%$ & 30.53 & 24.05 & 22.35 & 29.5 & 33.93 & 30.72 & 33.04 & 30.91 & 31.77 & 34.35 & 28.43 \\
\hline $\mathrm{C} \%$ & 19.58 & 26.96 & 27.88 & 20.54 & 16.24 & 19.69 & 17.11 & 19.12 & 18.24 & 16.65 & 22.27 \\
\hline G\% & 18.52 & 26.33 & 27.82 & 19.61 & 16.28 & 18.24 & 16.63 & 18.37 & 17.22 & 15.01 & 20.79 \\
\hline $\mathrm{A}+\mathrm{T} \%$ & 62.17 & 46.9 & 44.53 & 59.97 & 67.79 & 62.27 & 66.32 & 62.63 & 64.73 & 68.32 & 57.04 \\
\hline$C+G \%$ & 37.95 & 53.21 & 55.64 & 40.13 & 32.44 & 37.8 & 33.79 & 37.45 & 35.46 & 31.71 & 43.09 \\
\hline
\end{tabular}

Table 6: GC content of Vitis vinifera.

Arabidopsis and Spinacia, the discovery of the $y c f 1$ and $n d h f$ genes at the IRb / SSC binding site was identified, with the largest overlapping region in Arabidopsis with $37 \mathrm{bp}$ and the shortest in Solanum (17 bp). The $y c f 1$ is located between SSC and IRb regions, and it was duplicated in IRb at the border of IRb and SSC. In Spinacia, the $y c f 1$ has the longest repeat (1445 bp). While at Meskhuri mtsvane, the shortest duplication was detected (1109 bp).

\section{GC content}

The GC content of the total chloroplast genome of Vitis vinifera, Saperavi and Meskhuri mtsvane chloroplasts is similar and equals $37.4 \%$, the same number for other plants such as Solanum lycopersicum (37.86\%), Nicotiana tabacum (37.85\%), Atropa belladona (37.56\%) and Glycine max (34\%) have also been reported [14]. The coding and noncoding regions in each of the three genomes have a low GC content, which is reported as $40.13 \%$ and $33.79 \%$ respectively. The differences in GC content for four regions of all genomes of this study were analyzed and the Vitis vinifera's is presented in Table 6, and the results showed that IR region was the richest in all three genomes of this study. It seems that the ribosomal genes (rrna 4.5, rrna 5, rrna 16, rrna 23) and the coding regions responsible for the rich content of GC in IR [11,20,23]. GC content in the IR region in Vitis vinifera was $43.09 \%$, while GC content in SSC and LSC was $31.71 \%$ and $35.46 \%$, respectively. The distribution of GC content in each region similar with other species [11]. Studies on Alsophila spinulosa in 2009 have showed that GC content in the chloroplast genomes are not the same between genes in different functional groups, rRAN $(55.18 \%)>$ tRNA $(54.55 \%)>$ photosynthetic $(43.85 \%)>$ genetic system $(40.80 \%)>$ NADH $(39.54 \%)$ [8]. Similar results were reported for Vitis vinifera, Saperavi and Meskhuri mtsvane. In the coding region of Vitis vinifera, rRNA genes have the highest GC content (55.64\%) and the protein coding genes have the lowest (37.95\%). In non-coding region, GC content of IGS and introns is $32.44 \%$ and $37.80 \%$, respectively. GC content is a significant property of a genome, which is correlated to the gene expression regulation, number of microRNA binding sites, gene distribution and recombination rate and physical location of functional elements.

\section{References}

1. Kim KJ, Lee HL (2004) Complete chloroplast genome sequences from Korean ginseng (Panax schinseng Nees) and comparative analysis of sequence evolution among 17 vascular plants. DNA Res 11: 247-261.

2. Hirao T, Watanabe A, Kurita M, Kondo T, Takata K (2008) Complete nucleotide sequence of the Cryptomeria japonica D. chloroplast genome and comparative chloroplast genomics: Diversified genomic structure of coniferous species. BMC Plant Biol 23: 8-70.

3. Saski C, Lee SB, Daniell H, Wood TC, Tomkins J, et al. (2005) Complete chloroplast genome sequence of Gycine max and comparative analyses with 
Citation: Talat F, Shahdparvar S, Anarjan MB (2018) Comparative Bioinformatics Analyses of the Chloroplast Genomes of Vitis vinifera with Two Caucasica Subspecies of Grape Fruit. J Phylogenetics Evol Biol 6: 208. doi: 10.4172/2329-9002.1000208

Page 7 of 7

other legume genomes. Plant Mol Biol 59: 309-322.

4. Robert K, Jansen CK, Seung-Bum L (2006) Phylogenetic analyses of Vitis (Vitaceae) based on complete chloroplast genome sequences: effects of taxon sampling and phylogenetic methods on resolving relationships among rosids. BMC Evol Biol. 32: 1471-2148.

5. Leebens-Mack J, Raubeson LA, Cui L, Kuehl J, Fourcade MH, et al. (2005) Identifying the basal angiosperms in chloroplast genome phylogenies: sampling one's way out of the Felsenstein zone. Mol Biol Evol 22: 1948-1963.

6. Soltis DE, Soltis PS (2004) Amborella not a "basal angiosperm"? Not so fast. Amer J Bot 91: 997-1001.

7. Soltis DE, Albert VA, Savolainen V, Hilu K, Qiu YL, et al. (2004) Genome-scale data, angiosperm relationships, and 'ending incongruence': A cautionary tale in phylogenetics. Trends Plant Sci 9: 477-483.

8. Goremykin VV, Holland B, Hirsch-Ernst KI, Hellwig FH (2005) Analysis of Acorus calamus chloroplast genome and its phylogenetic implications. Mol Biol Evol 22: 1813-1822.

9. Lockhart PJ, Penny D (2005) The place of Amborella within the radiation of angiosperms. Trends Plant Sci 10: 201-203.

10. Ané C, Burleigh JG, McMahon MM, Sanderson MJ (2005) Covarion structure in plastid genome evolution: a new statistical test. Mol Biol Evol 22: 914-924.

11. Kim YK, Park CW, Kim KJ (2009) Complete chloroplast DNA sequence from a Korean endemic genus, megaleranthis saniculifolia, and its evolutionary implications. Mol Cells 27: 365-381.

12. Daniell H, Kumar S, Duformantel N (2005) Breakthrough in chloroplast genetic engineering of agronomical important crops. Trends Biotechnol 23: 238-245.

13. Ruf S, Karcher D, Bock R (2007) Determining the transgene containment level provided by chloroplast transformation. Proc Natl Acad Sci USA. 104: 69987002.

14. Talat F, Wang K (2015) Comparative bioinformatics analysis of the chloroplast genome of a wild diploid Gossypium and two cultivated allotetraploid species. Iran J Biotech 13: 47-56.

15. Wyman SK, Boore JL, Jansen RK (2004) Automatic annotation of organellar genomes with DOGMA. Bioinformatics 20: 3252-3255.

16. Lohse M, Drechsel O, Bock R (2007) Organellar Genome DRAW (OGDRAW): a tool for the easy generation of high-quality custom graphical maps of plastid and mitochondrial genomes. Curr Genet 52: 267-274.
17. Kurtz S, Choudhuri JV, Ohlebusch E, Schleiermacher C, Stoye J (2001) REPuter: the manifold applications of repeat analysis on a genomic scale. Nucleic Acids Res 29: 4633-4642.

18. Green-acre MJ (1984) Theory and applications of correspondence analysis Academic Press.

19. Maria DE (2001) Synonymous codon usage in bacteria. Curr Issu Mol Biol 3 : 91-97.

20. Gao L, Yi X, Yang YX, Su YJ, Wang T (2009) Complete chloroplast genome sequence of a tree fern Alsophila spinulosa: insights into evolutionary changes in fern chloroplast genomes. BMC Evol Biol 9: 130.

21. Wu FH, Kan DP, Lee SB, Daniell H, Lee YW (2009) Complete nucleotide sequence of Dendrocalamus latiflorus and Bambusa oldhamii chloroplas genomes. Tree Physiol 29: 847-856.

22. Samson N, Bausher MG, Lee SB, Jansen RK, Daniell H (2007) The complete nucleotide sequence of the coffee (Coffea arabica L.) chloroplast genome: Organization and implications for biotechnology and phylogenetic relationships amongst angiosperms. Plant Biotechnol J 5: 339-353.

23. Daniell H, Wurdack KG, Kanagaraj A, Lee SB, Saski C (2008) The complete nucleotide sequence of the cassava (Manihot esculenta) chloroplast genome and the evolution of atpF in Malpighiales: RNA editing and multiple losses of a group II intron. Theor Appl Genet 116: 723-737.

24. Steane DA (2005) Complete nucleotide sequence of the chloroplast genome from the Tasmanian blue gum, Eucalyptus globulus (Myrtaceae). DNA Res 12 $215-220$.

25. Wilson CA (2004) Phylogeny of Iris based on chloroplast matK gene and trnK intron sequence data. Mol Phylogenet Evol 33: 402-412.

26. Millen RS, Olmstead RG, Adams KL (2001) Many parallel losses of inf $A$ from chloroplast DNA during angiosperm evolution with multiple independent transfers to the nucleus. Plant Cell 13: 645-658.

27. Ohsako T, Ohnishi O (2001) Nucleotide sequence variation of the chloroplast trnK/matK region in two wild Fagopyrum (Polygonaceae) species, F.leptopodum and F.statice, Genes Genet Syst 76: 39-46.

28. Wilson CA (2004) Phylogeny of Iris based on chloroplast matK gene and trnK intron sequence data. Mol Phylogenet Evol 33: 402-412.

29. Yang M, Zhang X, Liu G (2010) The complete chloroplast genome sequence of date palm (Phoenix dactylifera L.) PLoS One 5: 143-152. 